to accord my hearty agreement with his timely protest against the advertising of a chair of chemistry at King's College, London, at the "princely salary" of $600 l$. a year.

Prof. Armstrong hopes that the profession will make no response. There is, however, little doubt that there will be a quite substantial competition for the post among the best of our chemical lecturers. The reason is, of course, that $600 l$. does appear to the university lecturer a princely plum worth scrambling for; it meáns for him at one jump an increase to from two to three times his present salary, and he knows that as the number of such relatively wellpaid posts is much smaller than the number of lecturers, it is his duty to his dependents to leave no chance untried.

That I am not drawing an exaggerated picture will be evident from a consideration of the following average salaries of non-professorial teachers, calculated from data which I have before me, derived from fifteen universities and university colleges:-

\begin{tabular}{|c|c|c|c|c|}
\hline $\begin{array}{c}\text { Service } \\
\text { year }\end{array}$ & & & $\begin{array}{l}\text { tumber of } \\
\text { cturers }\end{array}$ & Average salary \\
\hline$I-5$ & $\cdots$ & $\ldots$ & 119 & 171 \\
\hline $6-10$ & $\ldots$ & $\ldots$ & 85 & 193 \\
\hline I $1-15$ & $\ldots$ & $\ldots$ & 77 & 253 \\
\hline $16-20$ & $\cdots$ & $\ldots$ & 30 & 239 \\
\hline $2 \mathrm{I}-25$ & $\ldots$ & $\ldots$ & II & 263 \\
\hline $26-30$ & $\ldots$ & $\ldots$ & 4 & 297 \\
\hline $31-35$ & $\ldots$ & $\ldots$ & 3 & 273 \\
\hline
\end{tabular}

The professorial view of a salary of $600 \mathrm{l}$. is another matter. What the gentleman appointed to the chair at King's College will think a few years hence is also another matter.

The preliminary to any effort to maintain a reasonable professorial scale of remuneration by the abstention of lecturers from competing for what are for them really well-paid posts is to ensure the lecturer a reasonable living wage. And this, too, is Prof. Armstrong's solution put in rather different form. Why not call the post a lectureship? A glance at the above table will show that to abstain from competing for a $600 l$. post, simply because it is called a professorship, in, say, one's twelfth year of service, is a risk too grave to be taken.

The Scottish lecturers have been recently granted a graded scale rising to $75 \mathrm{ol}$. This is in line with the revised scheme of remuneration for the scientific staff of the National Physical Laboratory, as follows:-

\begin{tabular}{|c|c|c|c|c|}
\hline & & $\underset{f}{\operatorname{Min} .}$ & Yearly increase & $\underset{\digamma}{\operatorname{Max}}$ \\
\hline Superintendents & $\cdots$ & 800 & $5^{\circ}$ & 1000 \\
\hline Principal assistants & ... & $65^{\circ}$ & 25 & $75^{\circ}$ \\
\hline Senior assistants .. & $\ldots$ & 500 & 25 & 600 \\
\hline Assistants, I. .. & $\ldots$ & $35^{\circ}$ & 20 & $45^{\circ}$ \\
\hline Assistants, II. & $\ldots$ & $25^{\circ}$ & 20 & $35^{\circ}$ \\
\hline Junior assistants ... & $\ldots$ & 175 & I5 & 235 \\
\hline
\end{tabular}

In regard to abstention, another and very vital difliculty arises. How is a lecturer to know what his colleagues will do? He may by abstaining cut his own throat without achieving any reform. Both professors and lecturers are in a dilemma. What is to be done?

The answer is perfectly clear. We university teachers should have an association which would do for us, or enable us to do for ourselves, what the Medical Association does for the doctors. This is a perfectly practical suggestion. It mav be taken as certain that in the course of evolution such an association is destined to come. What is to prevent it from being an accomplished fact within six months from to-day? R. Douglas Laurie.

University College of Wales, Abervstwyth, January 9.

\section{Airy and the Figure of the Earth.}

I SHould be very much obliged if any reader of Natuke would kindly give me an answer to the following question :-

In a note on p. 37 I of the second volume of the treatise on "Natural Philosophy," by Thomson and Tait, I read: "Airy has estimated $24 \mathrm{ft}$. as the greatest deviation of the bounding surface from the true ellipsoid" Where did Airy give the result $24 \mathrm{ft}$.?

Darwin ("Scientific Papers," vol. iii., p. 78) writes: " $\Lambda$ iry further concluded that the earth's surface must be depressed below the level of the true ellipsoid in middle latitudes. He gave no numerical estimate of this depression, but expressed the opinion that it must be very small."

It is curious to remark that Todhunter, in his "History of the Theory of Attraction, etc.," made no mention of the paper by Airy on the figure of the earth printed in the third part of the Philosophical Transactions of the Royal Society for the year 1826, which is the paper alluded to in the above quotation from Darwin.

OtTavio ZanotTi Bianco

(Docent of Geodesy in the R. University of Turin).

Torino (Italy), Via della Rocca 28 , November $28,1918$.

I HAVE carefully examined the curious points raised by Sig. Bianco, and cannot find any satisfactory answer to the questions asked.

Thomson and Tait's footnote, in which it is stated that Airy "estimated $24 \mathrm{ft}$. as the greatest deviation of the bounding surface from the true ellipsoid," occurs also in the first edition of the "Natural Philosophy." It is true, in a sense, that Airy gave in his published paper no distinct numerical estimate of this deviation. Nevertheless, in his discussion of Sabine's pendulum observations, he compared the coefficients of certain terms with the corresponding values in terms of $e$ and $\mathrm{A}$ as given in his theoretical formula. The value of A so found (see Phil. Trans., vol. cxvi., p. 366 ) is 0.000064 . In latitude $45^{\circ}$ the deviation is $a \mathrm{~A} \times \frac{1}{2} \times \frac{1}{2}$, and this is $334 \mathrm{ft}$., and not $24 \mathrm{ft}$., as Thomson and Tait give it.

The only other possible explanation is that Airy had communicated a later estimate privately to Thomson, for it is quite conceivable that Airy may have made an estimate which he never published. I can find no other publication of his in which this estimate is given or from which it may be derived.

In the days in which Thomson and Tait were writing their book-i.e. in the "sixties" of last century-Thomson was much interested in the figure of the earth, and he was almost certain to be in touch with Airy.

Personally, I never thought of questioning the accuracy of the footnote. Sir George Darwin read the proof-sheets of the second edition and wrote a number of sections. He let it pass, although in his own writings he says that Airy gave no estimate. This, however, is not quite correct.

I can throw no further light on it. Possibly a better series of pendulum observations than those given by Sabine might lead to the result $24 \mathrm{ft}$. But that is rather a wild speculation.

C. G. KNOTT.

\section{Some Temperature Anomalies.}

I FIAVE often noticed the anomalies of temperature to which Mr. Harries directs attention in NATURE of January 9, and have sometimes been inclined to ascribe the high temperature in the east to air that 